\title{
CEA as a prognostic index in colorectal cancer
}

\author{
Department of Oncology, Discipline of Gastroenterology, UNIFESP - EPM - São Paulo, Brazil
}

\begin{abstract}
Introduction: The carcinoembryonic antigen, CEA, is the tumor marker most used in colorectal patients, principally during follow up after radical surgery. High serum CEA level before surgery is often associated with worse prognosis, in some studies. Objective: The purpose of this study was to evaluate the preoperative carcinoembryonic antigen levels (CEA) and the frequency of recurrence. Material and Methods: Eighty-three patients with colorectal cancer at Dukes stages A, B or C were evaluated retrospectively. The patients' follow up was at least two years or to death. CEA was detemined in serum by enzyme immunoassay (Sorin Biomedica), normal value $0-5 \mathrm{ng} / \mathrm{ml}$. Results: Disease recurrence was observed in 32 patients (38.5\%), 13 Dukes B and 19 Dukes C. Seventy five per cent of the patients with CEA higher than $10 \mathrm{ng} / \mathrm{ml}$ relapsed and $80 \%$ of the patients without recurrence had normal CEA. Disease recurrence in patients with preoperative elevated CEA occurred during the first year of follow up in $56 \%$ of the patients. Conclusion: Although the tumor stage is today the most valuable prognostic variable in colorectal cancer, the preoperative CEA value can provide some additional information in the prognosis of the patient.
\end{abstract}

UNITERMS: CEA. Colorectal cancer. Recurrence.

\section{INTRODUCTION}

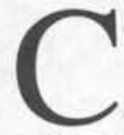

olorectal cancer is one of the most common cancers in industrialized cities. In Brazil, it is the 4th largest cause of cancer in women and the 6 th in men. In 1995, 22000 persons had colorectal cancer and 3000 died from this cancer in this country.

The carcinoembryonic antigen (CEA), first described by Gold and Freedman ${ }^{(1)}$ in 1965 , is a glycoprotein present in a high number $(90 \%)$ of colorectal adenocarcinoma. Serum determination of CEA is the the most widely used tumor marker in these patients. The main function of this marker is to detect early recurrence during follow up after radical surgery. The serum dosage of CEA at diagnosis has low sensitivity because patients with colorectal cancer can have normal levels of serum CEA. The relationship between high CEA serum levels in the preoperative period and worse

\author{
Address for correspondence: \\ Nora Manoukian Forones \\ Disciplina de Gastroenterologia - UNIFESP \\ Rua Botucatu, 720 \\ São Paulo/SP - Brasil - CEP 04023-000
}

prognosis has been investigated in several studies ${ }^{2,3,4.5}$, so far without definite conclusion. Patients with high CEA serum levels before surgery could have a higher incidence of recurrence than patients with normal levels.

The aim of this study was to retrospectively evaluate the serum CEA levels before surgery in operable colorectal cancer patients as a predictor of recurrence. The possible relationships between serum levels of CEA and sex, age, diameters of the tumor, histological diffentiation, tumor site (colon or rectum) and Dukes stage have also been evaluated.

\section{PATIENTS AND METHODS}

We retrospectively reviewed 83 patients with colorectal adenocarcinoma treated at the Gastroenterology division of the Hospital São Paulo. The mean age of the patients was 57 years (29-83 years), there being 42 women and 41 men. 44 had colon cancer and 39 rectal cancer. All had operable cancer. Staging was performed according to Dukes' stages (Dukes A in 3, Dukes B in 46 and Dukes C 
in 34). All the patients were followed for at least two years or up to death.

Serum samples were taken preoperatively, within 30 days of surgery and stored at $-20^{\circ} \mathrm{C}$. Serum levels of CEA were measured by Elisa, using the Sorin Biomedica kit. Normal values are from $0-5 \mathrm{ng} / \mathrm{ml}$. .

We calculated the sensitivity, specificity and positive and negative predictive value for CEA as an index of tumor recurrence. Statistical analysis consisted of Kruskal-Wallys analysis of variance or Chi square test. Significance was defined as $\mathrm{p}<0.05$.

\section{RESULTS}

The mean and standard mean error of CEA values in Dukes stages A, B and C were $2 \pm 1.96 ; 5.8 \pm 5.82 ; 23.6 \pm$ 23.59 (Table 1). There was no significant difference with respect to sex $(\mathrm{p}=0.94)$, age before or after 45 years $(p=0.94)$, cancer site $(p=0.77)$, diameter of the tumor $(\mathrm{p}=0.96)$, or histological differentiation $(\mathrm{p}=0.87)$.

The CEA values were differentiated in all three stages by the Kruskal-Wallys analysis $(p=0.043)$, in which patients with Dukes stage A were the same as those with stage $\mathrm{B}$, but those with stage $\mathrm{C}$ were different from both $\mathrm{A}$ and B. Among the 46 patients with Dukes stage B, 9 (34\%) had elevated serum CEA levels and among the 34 patients with stage C, 17 (50\%) had elevated CEA serum level. The 3 patients with Dukes'stage A had normal serum CEA levels (Table2).

Twenty six patients $(31 \%)$ had CEA levels greater than $5 \mathrm{ng} / \mathrm{ml}$ (Table 2). Disease recurrence was found in 32 patients, 13 Dukes B and 19 Dukes C, 22 had metastases, most ferquently in the liver $(57 \%)$, and 10 had local recurrence. CEA levels were elevated in 7 of the 12 patients who developed liver metastases. Before the completion of 1 year of follow up, 12 patients had relapsed. Among the 32 patients with recurrence of the disease during the follow up, 16 had preoperative elevated CEA serum levels and 16 had normal CEA levels. In 9 of the 16 patients with an elevated preoperative CEA, the recurrence appeared during the first year of follow up, while in the 16 with normal serum CEA level the diagnosis of recurrence was done after 1 year in $81 \%$ of the patients (Table 3 ). This difference was significant by the Chi square test $(\mathrm{p}=0.04)$.

Recurrence of the disease was observed in seventy five per cent of the patients with preoperative CEA levels greater than $10 \mathrm{ng} / \mathrm{ml}$. On the other hand, among the 51 patients without recurrence during the follow up, 41 (80\%)
Table 1

Mean \pm epm of CEA serum levels in Dukes stages.

\begin{tabular}{cccc}
\hline & Dukes A & Dukes B & Dukes C \\
$\mathrm{X} \pm \mathrm{epm}$ & $1.93 \pm 0.88$ & $5.82 \pm 1.86$ & $23.6 \pm 6.33$ \\
\hline
\end{tabular}

had normal CEA serum levels (Table 4). The Chi-square test between the patients with or without recurrence according to the serum CEA levels either normal or elevated, was statistically different $(\mathrm{p}=0.008)$.

The sensitivity, specificity, the positive predictive value and the negative predictive value are described in Table 5.

The frequency of recurrence according to Dukes stage was $28 \%$ for the B stage and $56 \%$ for the C stage. In Dukes stage B, the CEA level was elevated in $30 \%$ of the patients who developed recurrence, and normal in $82 \%$ of patients without recurrence. In Dukes stage C, 19 patients developed recurrence, of which $12(63 \%)$ had a CEA level greater than $5 \mathrm{ng} / \mathrm{ml}$. Among the other 15 patients without relapse, $10(67 \%)$ had normal serum levels. These differences were not significant by the Chi square test $(\mathrm{p}>0.05)$.

\section{DISCUSSION}

Thirty years after its description by Gold and Freedman (1), the CEA remains the tumor marker most studied in colorectal cancer, its main function being the monitoring of patients after the surgical resection of the tumor. The preoperative CEA level as a prognostic index is not yet defined, although many authors believe that the CEA level offers an additional criterion for evaluating the prognosis of colorectal cancer.

As in the majority of previous studies ${ }^{(2,4)}$, we also did not observed any differences of CEA levels when comparing sex, age, tumor site, tumor diameter or histological differentiation. Carpellan et. al. ${ }^{(6)}$, observed higher CEA sensitivity levels for rectal cancer than for colon cancer,

Table 2

Number of patients with CEA $>$ or $<5 \mathrm{ng} / \mathrm{ml}$ according to the Dukes stage

\begin{tabular}{ccc}
\hline Dukes stage & $<5$ & $>5$ \\
\hline A & 3 & 0 \\
B & 37 & 9 \\
C & 17 & 17 \\
\hline
\end{tabular}


Table 3

Number of patients with CEA $>$ or $<5 \mathrm{ng} / \mathrm{ml}$ and the time of recurrence

\begin{tabular}{ccc}
\hline Time of Recurrence & CEA $<5 \mathrm{ng} / \mathrm{ml}$ & CEA $>5 \mathrm{ng} / \mathrm{ml}$ \\
\hline$<1$ year & 3 & 9 \\
$>1$ year & 13 & 7 \\
\hline
\end{tabular}

attributing these differences to the fact that rectal cancer is more often infiltrative and annular.

The sensitivity of CEA at the time of diagnosis of the tumor at Dukes stages A or B was $18 \%$.and $50 \%$ at stage $\mathrm{C}$, which was a result similar to $\mathrm{Chu} \mathrm{et}^{\mathrm{al}}{ }^{(7)}$. The mean serum levels were higher for tumors in Dukes stage $C$ than for stages B or A. The differences in serum CEA were statistically significant. The CEA level differentiated Dukes stage $\mathrm{A}$ from $\mathrm{C}$, and $\mathrm{C}$ from $\mathrm{B}$, but not $\mathrm{A}$ from $\mathrm{B}$.

We observed, as in previous studies, that $38.5 \%$ of the patients relapsed. This percentage was higher in the patients with nodal involvement (Dukes C). In this group, the frequency of recurrence was $58 \%$ and the CEA level was elevated in $60 \%$ of the patients. The Gastrointestinal Tumor Study Group ${ }^{(8)}$ reported that patients with 4 or more nodal involvements and CEA level greater than $5 \mathrm{ng} / \mathrm{ml}$ had a higher risk of recurrence and decreased survival.

CEA preoperative levels were normal in $50 \%$ of the patients who developed recurrence and elevated in the others, and therefore patients with normal serum CEA level can develop recurrence during follow up. The sensitivity was lower than in the studies of Wang ${ }^{(9)}$ and Tate $^{(10)}$ but similar to McCall ${ }^{(11)}$. Seventy five per cent of patients with CEA level higher than $10 \mathrm{ng} / \mathrm{ml}$ developed recurrence, but on the other hand, among the 50 patients
Table 5

Number of patients with CEA $>$ or $<5 \mathrm{ng} / \mathrm{ml}$ and with or without recurrence

\begin{tabular}{lcc}
\hline & CEA $<5 \mathrm{ng} / \mathrm{ml}$ & CEA $>.5 \mathrm{ng} / \mathrm{ml}$ \\
\hline Recurrence & 16 & 16 \\
Without Recurrence & 41 & 10 \\
\hline
\end{tabular}

without recurrence, the CEA level were normal in $80 \%$. Tsushiya et $\mathrm{al}^{(4)}$ observed that patients with preoperative CEA level greater than $10 \mathrm{ng} / \mathrm{ml}$ in Dukes stage B or C had decreased survival rates. In the group of patients with elevated preoperative CEA and recurrence, this occurred in the first year of follow up. $\mathrm{Chu}^{(7)}$ and $\mathrm{Groslin}^{(3)}$ also reported that patients with elevated CEA level had recurrence after the first 6 months. Carpelan ${ }^{(12)}$ found a significant difference in survival in patients with preoperative serum CEA above $5 \mathrm{ng} / \mathrm{ml}$ and those with a lower CEA level. Northover ${ }^{(13)}$ reported that the risk of recurrent disease within two years of primary surgery was more than double in those whose serum CEA was raised preoperatively.

In this study we can conclude that preoperative CEA higher than $10 \mathrm{ng} / \mathrm{ml}$ was associated with poorer prognosis. In these patients the recurrence would be more frequently in the first year of follow up. The results from this series are consistent with several published works. Although the information provided by the tumor stage is still the most valuable prognostic variable today, the preoperative elevated CEA level provides additional information on the prospects for survival, suggesting a more aggressive tumor and probably identifying a subgroup of patients for adjuvant therapy.

Table 4

Sensitivity(S), specificity(E), positive predictive value (PPV) and negative predictive value (NPV)

$\mathrm{S}=\underline{\mathrm{N}} \mathrm{o}$ of patients with recurrence and preoperative CEA $>5$ № of patients with recurrence

$\mathrm{E}=\mathrm{N} N$ of patients without recurrence and preoperative CEA $<5$ № patients without recurrence

$P P V=\underline{N}$ of patients with elevated CEA and recurrence № of patients with elevated CEA

$\mathrm{NPV}=\underline{\mathrm{N} N o \text { of patients with normal CEA and without recurrence }}$ patients with normal CEA

$$
\begin{gathered}
S=\frac{16}{32}=50 \% \\
E=\underline{41}=80,4 \% \\
51
\end{gathered}
$$

$\mathrm{VPP}=16=61,5 \%$

26

VPN $=\underline{41}=72 \%$ 57 


\section{RESUMO}

Introdução: O antígeno carcinoembrionário, CEA é o marcador tumoral mais usado em pacientes com câncer colorretal, principalmente no acompanhamento clinico após ressecção cirúrgica do tumor. Niveis séricos elevados de CEA no préoperatório são frequentemente associados, em alguns estudos, a pior prognóstico. Objetivo: Comparar os niveis séricos de CEA no pré-operatório e a frequência da recorrência no acompanhamento clinico. Material e Métodos: Oitenta e três pacientes com câncer colorretal estadiados em Dukes A, B, e C foram avaliados retrospectivamente. Os pacientes foram acompanhados, por no mínimo dois anos ou até o óbito. O CEA sérico foi determinado por Elisa (Sorine Biomédicas, valor normal 0-5 ng/ml). Resultados: A recorrência foi observada em 32 pacientes (38.5\%), sendo 13 pacientes Dukes B e 19 Dukes C. Setenta e cinco por cento dos pacientes com CEA maior que $10 \mathrm{ng} / \mathrm{ml}$ apresentaram recorrência e oitenta por cento dos pacientes sem recorrência tinham niveis séricos de CEA dentro do valor de normalidade. Nos pacientes com CEA elevado no pré-operatório e que desenvolveram recorrência, esta ocorreu no primeiro ano de acompanhamento em $56 \%$ dos pacientes. Dezesseis pacientes foram a óbito durante o acompanhamento, 11 destes tinham CEA sérico aumentado no pré-operatório. Conclusão: Embora, o estadiamento clinico seja a variável mais usada na avaliação do prognóstico, os valores de CEA no pré-operatório podem fornecer algumas informações adicionais sobre o prognóstico do doente.

\section{REFERENCES}

1. Gold P.; Freedman SO. Demonstration of tumor-specific antigens in human colonic carcinomata by immunological tolerance and absorption techniques. J. Exp. Med. 1965; 121 : 439-62.

2. Barone C; Astone A; Cassano A; et al. Advanced colon cancer: Staging and prognosis by CEA Test. Oncology 1990; 47: 128-132.

3. Groslin R; Steele G JR; MacIntyre J; et al. The use of preoperative plasma CEA levels for the stratification of patients after curative resection of colorectal cancers. Ann. Surg. 1980; 192: 747-751.

4. Tsuchiya, A; Ando Y; Kikushi, Y; et al. Reappraisal of preoperative carcinoembryonic antigen levels as a prognostic factor in resectable colorectal cancer. J. Med. Sci., 1994; 40: 9-17.

5. Wanebo H.J.; Rao B.;Pinsky CM; et al. Preoperative carcinoembryonic antigen level as prognostic indicador in colorectal cancer. N. Engl. J. Med. 1978; 299: 448-451.

6. Carpelan-Holmstrom M.; Haglund C.H.; Roberts P. J.; Differences in serum tumor markers between colon and rectal cancer. Dis Colon Rectum 1996; 39:799-805.
7. Chu DZJ.; Erickson CA.; Russell P.; Thompson C.; Lang NP.; Broadwater RJ.; Westbrook KC; Prognostic significance of carcinoembryonic antigen in colorectal carcinoma. Arch Surg.1991; 126:314-316.

8. Steele, G.Jr.; Ellenberg, S.; Ramming, K et al. (GITSG). Carcinoembryonic antigen monitoring among patients in multinstitutional adjuvant G.I. therapy protocols. Ann. Surg. 1982; 196:162-9.

9. Wang, J.Y.; Tang, R. \& Chiang, M. Value of carcinoembryonic antigen in the management of colorectal cancer. Dis. Colon. Rectum;1994; 37: 272-7.

10. Tate H. Plasma CEA in the post-surgical monitoring of colorectal carcinoma. Br. J. Cancer. 1982; 46: 323-330.

11. McCall, JL.; Black, RB; Rich, CA., et al. The value of serum carcinoembryonic antigen in predicting recurrent disease following curative resection of colorectal cancer. Dis. Colon Rectum 1994; 37: 875-881.

12. Carpelan-Holmstrom M., Haglund C., Lundin J.; Preoperative serum levels of CA 242 and CEA predict outcome in colorectal cancer. Eur. Journal Cancer 1996; 32A: 11561161 .

13. Northover J. The use of prognostic markers in surgery for colorectal cancer. 1995: 31A:1207-1209. 